\title{
Winogradskyella thalassocola gen. nov., sp. nov., Winogradskyella epiphytica sp. nov. and Winogradskyella eximia sp. nov., marine bacteria of the family Flavobacteriaceae
}

Correspondence
Olga I. Nedashkovskaya
olganedashkovska@piboc.dvo.ru
or
olganedashkovska@yahoo.com

Bacteria of the family Flavobacteriaceae are often found attached to the surfaces of a diverse range of marine algae (Chan \& McManus, 1969; Bolinches et al., 1988; Hanzawa et al., 1998). The novel marine bacteria Arenibacter latericius, Cellulophaga fucicola, Cellulophaga baltica, Cellulophaga

Published online ahead of print on 19 July 2004 as DOI 10.1099/ ijs.0.63307-0.

†Present address: Department of Microbiology, School of Bioscience and Biotechnology, Chungnam National University, Yusong, Daejon 305-764, Republic of Korea.

The GenBank/EMBL/DDBJ accession numbers for the 16S rRNA gene sequences of Winogradskyella thalassocola KMM $3907^{\top}$, Winogradskyella epiphytica KMM $3906^{\top}$ and Winogradskyella eximia KMM 3944 ${ }^{\top}$ are AY521223, AY521224 and AY521225, respectively. algicola, Formosa algae, Mesonia algae, Maribacter ulvicola, Tenacibaculum amylolyticum, Ulvibacter litoralis and Zobellia galactanivorans, associated with different algae, have been isolated and described (Johansen et al., 1999; Bowman, 2000; Barbeyron et al., 2001; Suzuki et al., 2001; Ivanova et al., 2001, 2004; Nedashkovskaya et al., 2003b, 2004a, b). The abovementioned flavobacteria are commonly characterized by rodshaped cells. During studies on microbial communities of algae inhabiting the Sea of Japan, we recovered three novel isolates belonging to the family Flavobacteriaceae from the algae frond surfaces; these isolates were able to form cellular network-like structures or aggregates that can be considered to serve for an attachment adaptation.

Based on a polyphasic study of the algal isolates, including 
phylogenetic, genotypic, chemotaxonomic and phenotypic data, we propose a new genus, Winogradskyella gen. nov., containing three novel species.

Strains KMM $3906^{\mathrm{T}}$, KMM $3907^{\mathrm{T}}$ and $\mathrm{KMM} 3944^{\mathrm{T}}$ were isolated from the green alga Acrosiphonia sonderi, and the brown algae Chorda filum and Laminaria japonica, respectively, collected in the Gulf of Peter the Great of the Sea of Japan during June 2000 . Strains were cultivated at $28^{\circ} \mathrm{C}$ on marine agar 2216 (MA; Difco) and stored at $-80^{\circ} \mathrm{C}$ in marine broth 2216 (MB; Difco) supplemented with $20 \%$ $(\mathrm{v} / \mathrm{v})$ glycerol. On MA, colonies of strains studied were round, 2-4 mm in diameter, yellow-pigmented, shiny, viscous and with entire edges.

The phylogenetic position of the three isolates was determined using previously described procedures for DNA extraction, PCR and 16S rRNA gene sequence analysis (Kim et al., 1998). The sequence data were aligned with those of representative members of selected genera of the family Flavobacteriaceae by using PHYDIT version 3.2 (http:// plaza.snu.ac.kr/ jchun/phydit/). Phylogenetic trees were inferred by using suitable programs of the PHYLIP package (Felsenstein, 1993). Phylogenetic distances were calculated from the two-parameter model of Kimura (1980), and trees were constructed on the basis of the neighbourjoining (Saitou \& Nei, 1987), least-squares (Fitch \& Margoliash, 1967) and maximum-likelihood (Felsenstein, 1993) algorithms. Bootstrap analysis was performed with 1000 resampled datasets using the SEQBOOT and CONSENSE programs of the PHYLIP package.

Phylogenetic analysis of almost-complete 16S rRNA gene sequences of strains KMM $3906^{\mathrm{T}}$, KMM $3907^{\mathrm{T}}$ and KMM $3944^{\mathrm{T}}$ revealed that they form a distinct lineage within the family Flavobacteriaceae (Fig. 1). Psychroserpens burtonensis was found to be the nearest neighbour; this relationship was supported by a high bootstrap value and also by the different tree-making algorithms used. However, 16S rRNA gene sequence similarity between the three strains and $P$. burtonensis was only $93 \cdot 5-93 \cdot 8 \%$. 16S rRNA gene sequence similarity values of the three strains to other close relatives, Gelidibacter algens and Formosa algae, were 90.8-91.3 and $92 \cdot 7-92.9 \%$, respectively. The low sequence similarity values of KMM $3906^{\mathrm{T}}$, KMM $3907^{\mathrm{T}}$ and $\mathrm{KMM} 3944^{\mathrm{T}}$ to other Cytophaga-like bacteria described to date $(85 \cdot 6-$ $92 \cdot 1 \%)$ demonstrate that the bacteria isolated in this study represent a new genus.

The three strains had 16S rRNA gene sequence similarities in the range $96 \cdot 3-97 \cdot 1 \%$.

For DNA-DNA hybridizations and determination of the $\mathrm{G}+\mathrm{C}$ content, DNA was isolated following the method of Marmur (1961). The G $+\mathrm{C}$ content was determined by the thermal denaturation method of Marmur \& Doty (1962). DNA-DNA hybridization was performed spectrophotometrically and initial renaturation rates were recorded as described by De Ley et al. (1970).
The DNA G + C contents of strains KMM $3906^{\mathrm{T}}$, KMM $3907^{\mathrm{T}}$ and $\mathrm{KMM} 3944^{\mathrm{T}}$ were $35 \cdot 2$, $34 \cdot 6$ and $36 \cdot 1 \mathrm{~mol} \%$, respectively. DNA-DNA relatedness between the strains was $34-45 \%$. These values indicated that the strains represent three separate species. Phenotypic data distinguishing the strains are given in Table 1.

Analysis of fatty acid methyl esters was carried out according to the standard protocol of the Microbial Identification System (Microbial ID). Isoprenoid quinones were extracted from lyophilized cells and analysed as described by Akagawa-Matsushita et al. (1992). Isoprenoid quinone composition was characterized by HPLC (Shimadzu Instruments) using a reversed-phase type Zorbax ODS column $(250 \times 4.6 \mathrm{~mm})$ and acetonitrile/ 2-propanol $(65: 35, \mathrm{v} / \mathrm{v})$ as a mobile phase at a flow rate of $0.5 \mathrm{ml} \mathrm{min}{ }^{-1}$. The column was kept at $40{ }^{\circ} \mathrm{C}$. Menaquinones were detected by monitoring at $270 \mathrm{~nm}$ and were identified by comparison with known quinones from reference strain Salegentibacter salegens DSM $5424^{\mathrm{T}}$.

Predominant cellular fatty acids of the strains studied were branched-chain unsaturated and straight-chain saturated, namely iso- $\mathrm{C}_{15: 0}$, anteiso- $\mathrm{C}_{15: 0}$, iso- $\mathrm{C}_{15: 1}$, iso- $\mathrm{C}_{16: 0}-3 \mathrm{OH}$

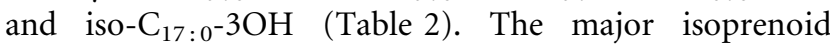
quinone was MK-6.

Phenotypic characterization was performed using the tests described previously (Nedashkovskaya et al., 2003a, b). Gliding motility was determined as described by Bowman (2000). Scanning electron microscopy was used to examine the bacteria, which were fixed with a solution containing $2 \%$ glutaraldehyde and 3\% formaldehyde in cacodylate buffer $(0 \cdot 1 \mathrm{M}$ cacodylate, $0.09 \mathrm{M}$ sucrose, $0.01 \mathrm{M} \mathrm{CaCl}_{2}, 0.01 \mathrm{M} \mathrm{MgCl}_{2}, \mathrm{pH} \mathrm{6.9)}$ for $1 \mathrm{~h}$ on ice and washed with cacodylate buffer. After washing several times in TE buffer (20 mM Tris, $1 \mathrm{mM}$ EDTA, pH 7·0), samples were dehydrated through a graded series of acetone $(10,30$, $50,70,90,100 \%)$ on ice, each step for $15 \mathrm{~min}$, followed by critical-point drying with liquid $\mathrm{CO}_{2}$. Samples were sputtercoated with an approximately $10 \mathrm{~nm}$ thick gold film before examination in a Zeiss field-emission scanning electron microscope (DSM982 Gemini) at an acceleration voltage of $5 \mathrm{kV}$ using the Everhart Thornley secondary electron (SE) detector and the Inlens-SE detector at a 50:50 ratio.

The three bacteria described in this study were Gramnegative, chemo-organotrophic with respiratory-type metabolism, non-motile single flexible rods, $0 \cdot 4-0.6 \mu \mathrm{m}$ in diameter and $1 \cdot 0-1 \cdot 3 \mu \mathrm{m}$ in length. All three strains formed unique network-like structures or aggregates (Fig. 2A-C). Growth of strain KMM $3944^{\mathrm{T}}$ was observed at $1-5 \% \mathrm{NaCl}$; strains $\mathrm{KMM} 3906^{\mathrm{T}}$ and $\mathrm{KMM} 3907^{\mathrm{T}}$ grew in media containing 1-8\% NaCl. Optimal growth was observed at $1 \cdot 5-2 \% \mathrm{NaCl}$. The maximum growth temperature for strain KMM $3906^{\mathrm{T}}$ was $37^{\circ} \mathrm{C}$, and that for strains KMM $3907^{\mathrm{T}}$ and KMM $3944^{\mathrm{T}}$ was $33^{\circ} \mathrm{C}$. Strain KMM $3906^{\mathrm{T}}$ was able to oxidize carbohydrates, but the other two strains were not. 


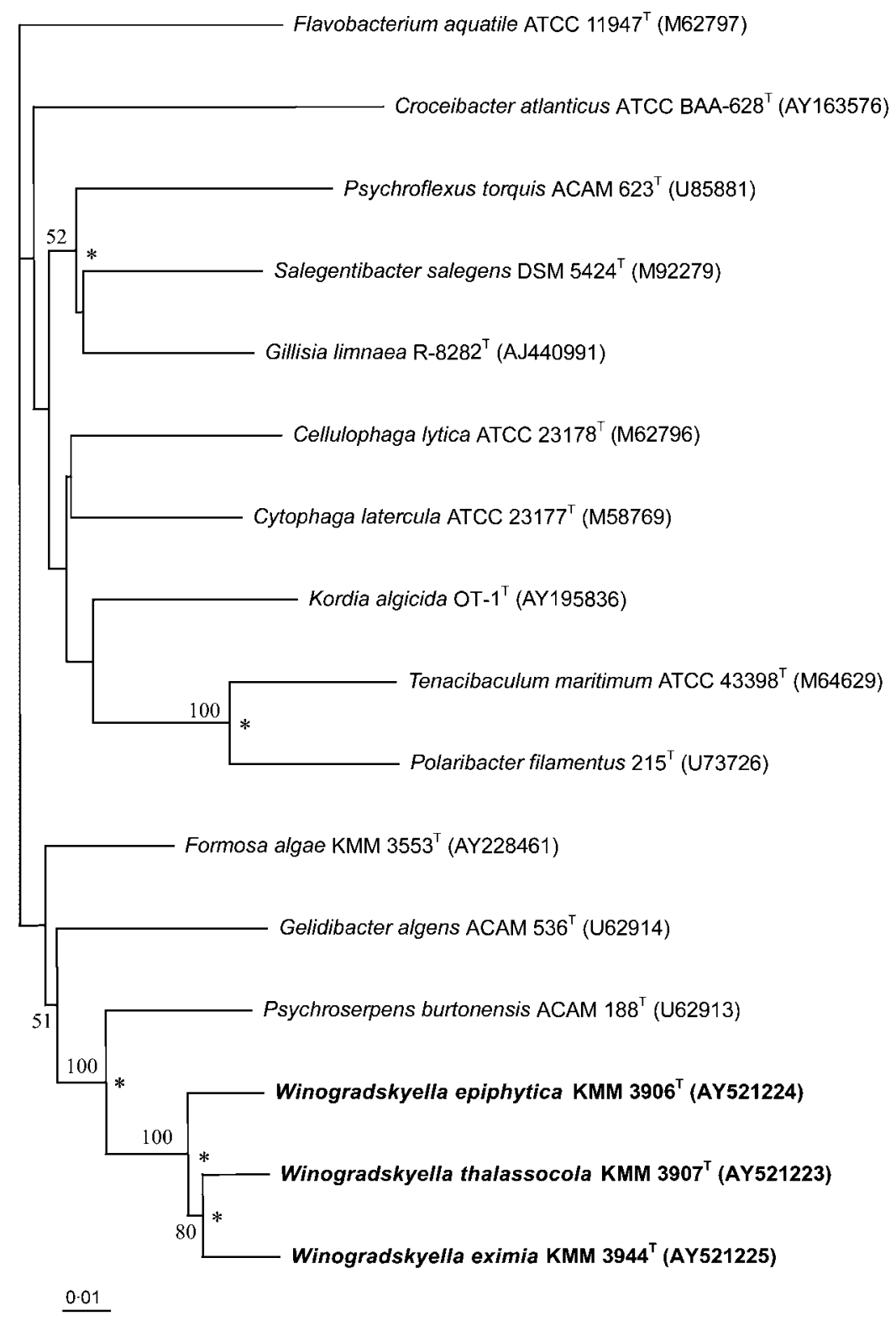

Fig. 1. Phylogenetic tree based on 16S rRNA gene sequence analysis of

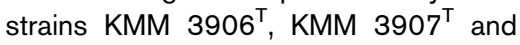
KMM $3944^{\top}$ and representative members of the family Flavobacteriaceae. Asterisks indicate branches that were also recovered using the maximumlikelihood algorithm. The numbers at nodes indicate percentage bootstrap values. Bar, 0.01 substitution per nucleotide position.

Other physiological characteristics of the three strains are given in the species description and in Table 1.

The three isolates occupy a distinct phylogenetic branch and share many common phenotypic traits with other members of the family Flavobacteriaceae. Differential features of strains studied and their close relatives are given in Table 3. The algal isolates can be distinguished from their closest relative $P$. burtonensis by the presence of gliding motility, oxidase activity and hydrolysis of agar and casein. The ability to produce oxidase and agarase distinguishes the strains studied and members of the genus Gelidibacter. The requirement of $\mathrm{Na}^{+}$ions for growth and casein hydrolysis separate the strains studied from their close neighbour Formosa algae.

Polyphasic data on the strains studied, including their separate phylogenetic branching, morphological characteristics, fatty acid composition, phenotypic features and low levels of DNA-DNA relatedness, indicate that they can not be assigned to any of the taxa currently included in the family Flavobacteriaceae. Consequently, we propose that strains KMM $3907^{\mathrm{T}}$, KMM $3906^{\mathrm{T}}$ and $\mathrm{KMM} 3944^{\mathrm{T}}$ be placed in a new genus, Winogradskyella gen. nov., as Winogradskyella thalassocola sp. nov., Winogradskyella epiphytica sp. nov. and Winogradskyella eximia sp. nov., respectively.

\section{Description of Winogradskyella gen. nov.}

Winogradskyella [Wi.no.grad'sky.el.la. N.L. fem. n. Winogradskyella named after Sergey Winogradsky (1856-1953), a Russian microbiologist who made a considerable contribution to the taxonomy of bacteria of the phylum Cytophaga-Flavobacterium-Bacteroides]. 
Table 1. Phenotypic properties of the Winogradskyella gen. nov. species

Taxa: 1, W. thalassocola $\mathrm{KMM} 3907^{\mathrm{T}}$; 2, W. epiphytica $\mathrm{KMM}$ $3906^{\mathrm{T}} ; 3$, W. eximia $\mathrm{KMM} 3944^{\mathrm{T}}$. All were positive for: respiratory metabolism; gliding motility; oxidase, catalase and alkaline phosphatase activities; requirement for $\mathrm{Na}^{+}$ions for growth; growth at $33{ }^{\circ} \mathrm{C}$ and in $1-5 \% \mathrm{NaCl}$; hydrolysis of agar, gelatin and Tween 40 ; susceptibility to carbenicillin and lincomycin. All were negative for: flexirubin pigments; nitrate reduction; urease and $\beta$-galactosidase activities; hydrolysis of cellulose (carboxymethylcellulose, filter paper) and chitin; acid formation from L-arabinose, D-galactose, D-lactose, D-melibiose, L-rhamnose, DL-xylose, adonitol, dulcitol, inositol, sorbitol and citrate; utilization of L-arabinose, D-lactose, D-sucrose, inositol, mannitol, sorbitol, malonate and citrate; indole, acetoin and $\mathrm{H}_{2} \mathrm{~S}$ production; susceptibility to benzylpenicillin, gentamicin, kanamycin, neomycin, polymyxin B and streptomycin.

\begin{tabular}{|c|c|c|c|}
\hline Characteristic & 1 & 2 & 3 \\
\hline \multicolumn{4}{|l|}{ Degradation of: } \\
\hline Casein & - & - & + \\
\hline Starch & - & - & + \\
\hline Tween 20 & - & + & + \\
\hline Tween 80 & - & + & - \\
\hline DNA & - & + & - \\
\hline \multicolumn{4}{|l|}{ Growth at/in: } \\
\hline $37^{\circ} \mathrm{C}$ & - & + & - \\
\hline $8 \% \mathrm{NaCl}$ & + & + & - \\
\hline \multicolumn{4}{|l|}{ Acid formation from: } \\
\hline D-Glucose & + & - & + \\
\hline D-Maltose & + & - & + \\
\hline D-Cellobiose & + & - & - \\
\hline D-Sucrose & - & - & + \\
\hline Mannitol & - & - & + \\
\hline \multicolumn{4}{|l|}{ Utilization of: } \\
\hline D-Glucose & + & - & + \\
\hline D-Mannose & + & - & + \\
\hline \multicolumn{4}{|l|}{ Susceptibility to: } \\
\hline Ampicillin & - & + & - \\
\hline Oleandomycin & + & + & - \\
\hline Tetracycline & - & + & + \\
\hline DNA G $+\mathrm{C}$ content $(\mathrm{mol} \%)$ & $34 \cdot 6$ & $35 \cdot 2$ & $36 \cdot 1$ \\
\hline
\end{tabular}

Rod-shaped cells, motile by gliding. The cells can form network-like structures. Gram-negative. Do not form endospores. Strictly aerobic. Produce non-diffusible yellow pigments. No flexirubins are formed. Chemoorganotrophic. Cytochrome oxidase-, catalase- and alkaline phosphatase-positive. Can hydrolyse gelatin, starch and DNA. The main cellular fatty acids are straight-chain saturated, branched-chain saturated and unsaturated fatty acids iso- $\mathrm{C}_{15: 0}$, anteiso- $\mathrm{C}_{15: 0}$, iso- $\mathrm{C}_{15: 1}$, iso- $\mathrm{C}_{16: 0}-3 \mathrm{OH}$ and iso- $\mathrm{C}_{17: 0^{-}} \mathrm{3OH}$. On the basis of $16 \mathrm{~S}$ rRNA gene sequence analysis, the genus Winogradskyella is a member of the family Flavobacteriaceae, phylum 'Bacteroidetes'.

The type species is Winogradskyella thalassocola.
Table 2. Whole-cell fatty acid profiles (percentage composition) of the Winogradskyella species

Taxa: 1, W. thalassocola KMM $3907^{\mathrm{T}}$; 2, W. epiphytica KMM $3906^{\mathrm{T}}$; 3, W. eximia KMM $3944^{\mathrm{T}}$.

\begin{tabular}{|c|c|c|c|}
\hline Fatty acid & 1 & 2 & 3 \\
\hline iso- $\mathrm{C}_{14: 0}$ & $2 \cdot 6$ & $4 \cdot 5$ & $1 \cdot 4$ \\
\hline iso- $\mathrm{C}_{14: 1}$ & & $1 \cdot 4$ & \\
\hline iso- $\mathrm{C}_{15: 0}$ & $8 \cdot 7$ & $6 \cdot 7$ & $25 \cdot 6$ \\
\hline anteiso- $\mathrm{C}_{15: 0}$ & $4 \cdot 9$ & $15 \cdot 9$ & $7 \cdot 0$ \\
\hline iso- $\mathrm{C}_{15: 1}$ & $11 \cdot 4$ & $8 \cdot 1$ & $10 \cdot 4$ \\
\hline anteiso- $\mathrm{C}_{15: 1}$ & $1 \cdot 6$ & $6 \cdot 3$ & $1 \cdot 4$ \\
\hline $\mathrm{C}_{15: 0}$ & $7 \cdot 9$ & $1 \cdot 2$ & $6 \cdot 7$ \\
\hline $\mathrm{Cl}_{5: 1} \omega 6 c$ & $6 \cdot 5$ & & \\
\hline iso- $\mathrm{C}_{16: 0}$ & $0 \cdot 8$ & $3 \cdot 7$ & $5 \cdot 7$ \\
\hline iso- $\mathrm{C}_{16: 1}$ & $2 \cdot 7$ & $3 \cdot 5$ & $4 \cdot 7$ \\
\hline $\mathrm{C}_{16: 0} 10$ methyl & & & $6 \cdot 3$ \\
\hline $\mathrm{C}_{16: 1} \omega 7$, iso- ${ }^{\mathrm{C} 15: 0^{-}}-2 \mathrm{OH}$ & $4 \cdot 2$ & $5 \cdot 1$ & $6 \cdot 1$ \\
\hline iso- $\mathrm{C}_{17: 1} \omega 9 c$ & $0 \cdot 6$ & $1 \cdot 1$ & \\
\hline anteiso- $\mathrm{C}_{17: 1}$ & & & $2 \cdot 3$ \\
\hline $\mathrm{C}_{17: 0}$ cyclo & & & $2 \cdot 4$ \\
\hline $\mathrm{C}_{17: 1} \omega 6 c$ & $0 \cdot 9$ & $1 \cdot 9$ & \\
\hline iso- $\mathrm{C}_{14: 0}-3 \mathrm{OH}$ & $0 \cdot 9$ & $1 \cdot 6$ & \\
\hline $\mathrm{C}_{15: 0}-2 \mathrm{OH}$ & $1 \cdot 8$ & $3 \cdot 3$ & $1 \cdot 0$ \\
\hline iso- $\mathrm{C}_{15: 0}-3 \mathrm{OH}$ & $11 \cdot 9$ & $2 \cdot 9$ & $2 \cdot 6$ \\
\hline $\mathrm{C}_{15: 0}-3 \mathrm{OH}$ & $2 \cdot 5$ & & \\
\hline iso- $\mathrm{C}_{16: 0}-3 \mathrm{OH}$ & $18 \cdot 1$ & $17 \cdot 1$ & $3 \cdot 2$ \\
\hline $\mathrm{C}_{16: 0-3 \mathrm{OH}}$ & $1 \cdot 0$ & & \\
\hline iso- $\mathrm{C}_{17: 0}-3 \mathrm{OH}$ & $5 \cdot 4$ & $7 \cdot 3$ & $6 \cdot 7$ \\
\hline $\mathrm{C}_{17: 0-2 \mathrm{OH}}$ & $0 \cdot 8$ & $5 \cdot 2$ & $1 \cdot 0$ \\
\hline Unknown & $4 \cdot 8$ & $3 \cdot 7$ & $5 \cdot 6$ \\
\hline
\end{tabular}

\section{Description of Winogradskyella thalassocola sp. nov.}

Winogradskyella thalassocola (tha.las.so.co'la. Gr. n. thalassa the sea; L. suffix -cola dweller; N.L. n. thalassocola a sea-dweller).

Main characteristics are as given for the genus. In addition, cells are $0 \cdot 5-0 \cdot 7 \mu \mathrm{m}$ in width and $4-7 \cdot 3 \mu \mathrm{m}$ in length. On $\mathrm{MA}$, colonies are $2-4 \mathrm{~mm}$ in diameter, circular, shiny with entire edges, yellow-pigmented and viscous. Growth occurs at $4-33^{\circ} \mathrm{C}$. Optimal temperature for growth is $21-23^{\circ} \mathrm{C}$. Growth occurs in 1-8\% NaCl. Decomposes gelatin and Tween 40. Does not hydrolyse starch, DNA, Tween 20, Tween 80, urea, cellulose (carboxymethylcellulose and filter paper) or chitin. Forms acid from D-glucose, D-maltose and D-cellobiose, but not from L-arabinose, D-galactose, D-lactose, D-melibiose, L-rhamnose, D-sucrose, DL-xylose, citrate, adonitol, dulcitol, inositol or mannitol. Utilizes D-glucose and D-mannose, but not L-arabinose, D-lactose, D-sucrose, mannitol, inositol, sorbitol, malonate or citrate. $\beta$-Galactosidase activity is negative. Nitrate is not reduced. $\mathrm{H}_{2} \mathrm{~S}$, indole and acetoin (Voges-Proskauer reaction) production are negative. Susceptible to 

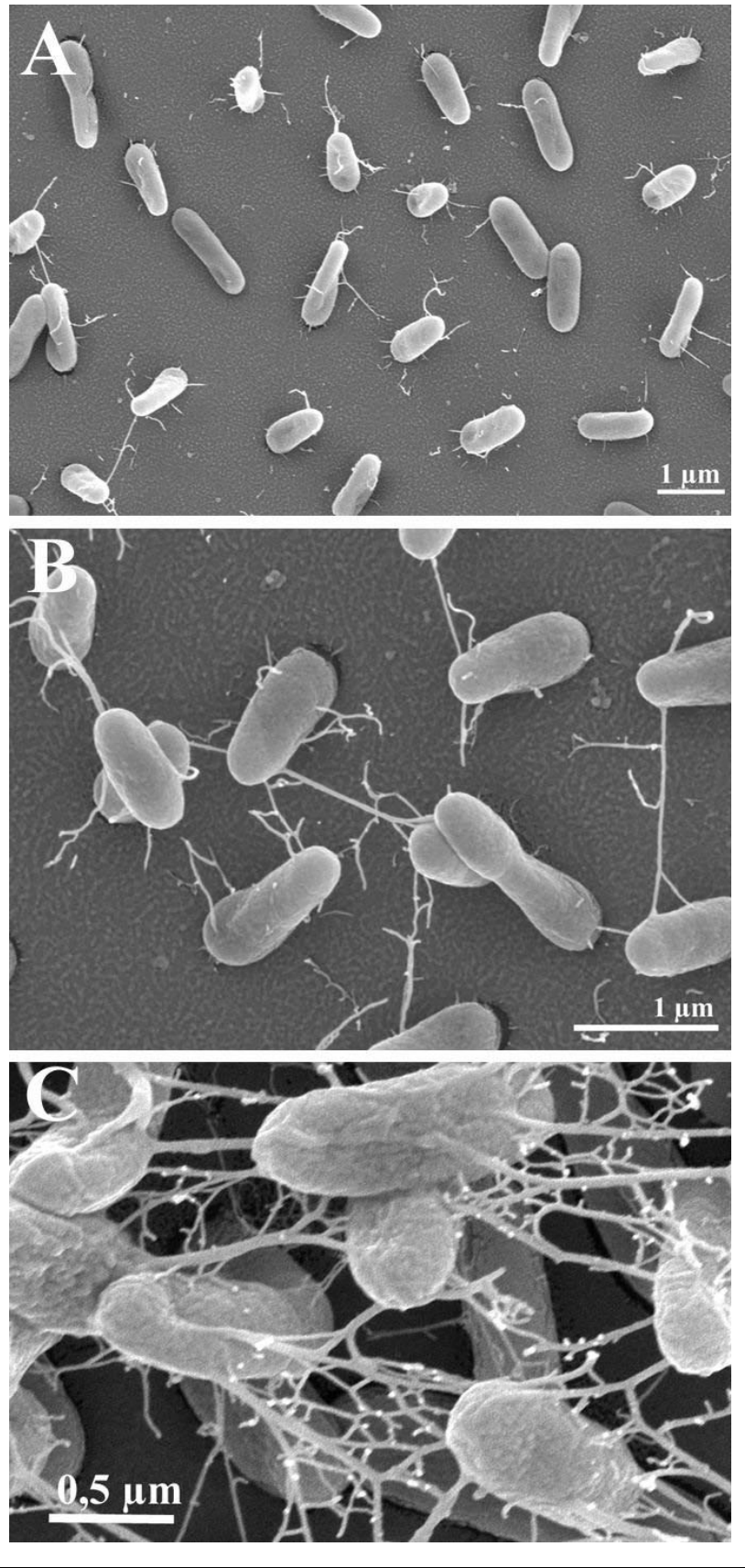

Fig. 2. Scanning electron micrographs of cells of strain KMM $3907^{\top}$ (A, B, C) showing the rod-shaped morphology and network-like structures.

carbenicillin, lincomycin and oleandomycin, but resistant to ampicillin, benzylpenicillin, gentamicin, kanamycin, neomycin, polymyxin $B$, streptomycin and tetracycline. The DNA G $+\mathrm{C}$ content is $34 \cdot 6 \mathrm{~mol} \%$.

The type strain, KMM $3907^{\mathrm{T}}$ (=KCTC $12221^{\mathrm{T}}=\mathrm{LMG}$ $22492^{\mathrm{T}}=$ DSM $\left.15363^{\mathrm{T}}\right)$, was isolated from the brown alga Chorda filum, collected in Troitsa Bay, Gulf of Peter the Great, Sea of Japan.
Table 3. Differential characteristics of the genus Winogradskyella and allied genera of the family Flavobacteriaceae

Genera: 1, Winogradskyella; 2, Psychroserpens; 3, Gelidibacter; 4, Formosa. Data from Bowman et al. (1997), Macián et al. (2002), Ivanova et al. (2004) and this study. -, Negative; +, positive; V, variable; ND, not determined.

\begin{tabular}{|lcccc|}
\hline Characteristic & $\mathbf{1}$ & $\mathbf{2}$ & $\mathbf{3}$ & $\mathbf{4}$ \\
\hline Gliding motility & + & - & + & + \\
Oxidase/catalase & $+/+$ & $-/+$ & $-/+$ & $+/+$ \\
Requirement for $\mathrm{Na}^{+}$for growth & + & + & + & - \\
Acid from carbohydrates & $\mathrm{V}$ & - & + & + \\
Hydrolysis of: & & & & \\
$\quad$ Agar & + & - & - & - \\
Casein & - & + & $\mathrm{V}$ & - \\
Gelatin & $\mathrm{V}$ & $\mathrm{V}$ & $\mathrm{V}$ & + \\
Starch & $\mathrm{V}$ & - & + & + \\
$\quad$ DNA & $\mathrm{V}$ & - & $\mathrm{V}$ & - \\
DNA G+C content (mol\%) & $34-37$ & $27-29$ & $36-40$ & $34-35$ \\
\hline
\end{tabular}

\section{Description of Winogradskyella epiphytica sp. nov.}

Winogradskyella epiphytica (e.pi.phy'ti.ca. epiphiticus -a -um adj. derived from Gr. epi on and phyt- relating to plants; N.L. epiphytica onto plant, pertaining to the original isolation from the surface of the algal fronds).

Main characteristics are as given for the genus. In addition, cells are $0 \cdot 5-0 \cdot 7 \mu \mathrm{m}$ in width and $4-7 \cdot 3$ in length. On $\mathrm{MA}$, colonies are $2-4 \mathrm{~mm}$ in diameter, circular, shiny with entire edges, yellow-pigmented and viscous. Growth occurs at $4-37^{\circ} \mathrm{C}$. Optimal temperature for growth is $23-25^{\circ} \mathrm{C}$. Growth occurs in $1-8 \% \mathrm{NaCl}$. Decomposes agar, gelatin, DNA, and Tween 20, Tween 40 and Tween 80. Does not hydrolyse starch, urea, cellulose (carboxymethylcellulose and filter paper) or chitin. Does not form acid from L-arabinose, Dcellobiose, D-galactose, D-glucose, D-lactose, D-maltose, D-melibiose, L-rhamnose, D-sucrose, DL-xylose, citrate, adonitol, dulcitol, inositol or mannitol. Does not utilize L-arabinose, D-glucose, D-lactose, D-mannose, Dsucrose, mannitol, inositol, sorbitol, malonate or citrate. $\beta$-Galactosidase activity is negative. Nitrate is not reduced. $\mathrm{H}_{2} \mathrm{~S}$, indole and acetoin (Voges-Proskauer reaction) production are negative. Susceptible to ampicillin, carbenicillin, lincomycin, oleandomycin and tetracycline, but resistant to benzylpenicillin, gentamicin, kanamycin, neomycin, polymyxin $\mathrm{B}$ and streptomycin. The DNA G $+\mathrm{C}$ content is $35 \cdot 2 \mathrm{~mol} \%$.

The type strain, KMM $3906^{\mathrm{T}}\left(=\mathrm{KCTC} 12220^{\mathrm{T}}=\mathrm{LMG}\right.$ $22491^{\mathrm{T}}=$ CCUG $47091^{\mathrm{T}}$ ), was isolated from the green alga Acrosiphonia sonderi, collected in Troitsa Bay, Gulf of Peter the Great, Sea of Japan. 


\section{Description of Winogradskyella eximia sp. nov.}

Winogradskyella eximia (e.xi'mi.a. L. fem. adj. eximia excellent).

Main characteristics are as given for the genus. In addition, cells are $0 \cdot 5-0 \cdot 7 \mu \mathrm{m}$ in width and $4-7 \cdot 3$ in length. On MA, colonies are $2-4 \mathrm{~mm}$ in diameter, circular, shiny with entire edges, yellow-pigmented and viscous. Growth occurs at $4-33^{\circ} \mathrm{C}$. Optimal temperature for growth is $21-23^{\circ} \mathrm{C}$. Growth occurs in 1-5\% NaCl. Decomposes casein, gelatin, starch, Tween 20 and Tween 40. Does not hydrolyse DNA, urea, Tween 80, cellulose (carboxymethylcellulose and filter paper) or chitin. Forms acid from D-glucose, D-maltose, D-sucrose and mannitol, but not from L-arabinose, Dcellobiose, D-galactose, D-lactose, D-melibiose, L-rhamnose, DL-xylose, citrate, adonitol, dulcitol or inositol. Utilizes Dglucose and D-mannose, but not L-arabinose, D-lactose, D-sucrose, mannitol, inositol, sorbitol, malonate or citrate. $\beta$-Galactosidase activity is negative. Nitrate is not reduced. $\mathrm{H}_{2} \mathrm{~S}$ is produced but indole and acetoin (Voges-Proskauer reaction) are not. Susceptible to lincomycin, but resistant to ampicillin, benzylpenicillin, carbenicillin, gentamicin, kanamycin, oleandomycin, neomycin, polymyxin B, streptomycin and tetracycline. The DNA G $+\mathrm{C}$ content is $36 \cdot 1 \mathrm{~mol} \%$.

The type strain, KMM $3944^{\mathrm{T}}$ (=KCTC $12219^{\mathrm{T}}=\mathrm{LMG}$ $22474^{\mathrm{T}}$ ), was isolated from the brown alga Laminaria japonica, collected in the Gulf of Peter the Great, Sea of Japan.

\section{Acknowledgements}

This research was supported by grants from the Ministry for Industry, Science and Technologies of the Russian Federation no. 2-2.16, and from the Presidium of the Russian Academy of Sciences 'Molecular and Cell Biology' and Russian Foundation for Basic Research no. 02-0449517. K. S. Bae, S. K. Han and S. B. Kim are also grateful for the support from the Korea Research Council of Fundamental Science \& Technology (grant no. KBM1000212).

\section{References}

Akagawa-Matsushita, M., Itoh, T., Katayama, Y., Kuraishi, H. \& Yamasato, K. (1992). Isoprenoid quinone composition of some marine Alteromonas, Marinomonas, Deleya, Pseudomonas and Shewanella species. J Gen Microbiol 138, 2275-2281.

Barbeyron, T., L'Haridon, S., Corre, E., Kloareg, B. \& Potin, P. (2001). Zobellia galactanovorans gen. nov., sp. nov., a marine species of Flavobacteriaceae isolated from red alga, and classification of [Cytophaga] uliginosa (ZoBell and Upham 1944) Reichenbach 1989 as Zobellia uliginosa gen. nov., comb. nov. Int J Syst Evol Microbiol 51, 985-997.

Bolinches, J., Lemos, M. L. \& Barja, J. L. (1988). Population dynamics of heterotrophic bacterial communities associated with Fucus vesiculosis and Ulva rigida in an estuary. Microb Ecol 15, 345-357.

Bowman, J. P. (2000). Description of Cellulophaga algicola sp. nov., isolated from the surfaces of Antarctic algae, and reclassification of Cytophaga uliginosa (ZoBell and Upham 1944) Reichenbach 1989 as Cellulophaga uliginosa comb. nov. Int J Syst Evol Microbiol 50, 1861-1868.
Bowman, J. P., McCammon, S. A., Brown, J. L., Nichols, P. D. \& McMeekin, T. A. (1997). Psychroserpens burtonensis gen. nov., sp. nov., and Gelidibacter algens gen. nov., sp. nov., psychrophilic bacteria isolated from Antarctic lacustrine and sea ice habitats. Int J Syst Bacteriol 47, 670-677.

Chan, E. C. S. \& McManus, E. A. (1969). Distribution, characterization, and nutrition of marine microorganisms from the algae Polysiphonia lanosa and Ascophyllum nodosum. Can J Microbiol 15, 409-420.

De Ley, J., Cattoir, H. \& Reynaerts, A. (1970). The quantitative measurement of DNA hybridization from renaturation rates. Eur J Biochem 12, 133-142.

Felsenstein, J. (1993). PHYLIP (phylogeny inference package), version 3.5. Department of Genetics, University of Washington, Seattle, USA.

Fitch, W. M. \& Margoliash, E. (1967). Construction of phylogenetic trees. Science 155, 279-284.

Hanzawa, N., Nakanishi, K., Nishijima, M. \& Saga, N. (1998). $16 \mathrm{~S}$ rDNA-based phylogenetic analysis of marine flavobacteria that induce algal morphogenesis. J Mar Biotechnol 6, 80-82.

Ivanova, E. P., Nedashkovskaya, O. I., Chun, J. \& 7 other authors (2001). Arenibacter gen. nov., a new genus of the family Flavobacteriaceae and description of a new species, Arenibacter latericius sp. nov. Int J Syst Evol Microbiol 51, 1987-1995.

Ivanova, E. P., Alexeeva, Y. A., Flavier, S., Wright, J. P., Zhukova, N. V., Gorshkova, N. M., Mikhailov, V. V., Nicolau, D. V. \& Christen, R. (2004). Formosa algae gen. nov., sp. nov., a novel member of the family Flavobacteriaceae. Int J Syst Bacteriol 54, 705-711.

Johansen, J. E., Nielsen, P. \& Sjøholm, C. (1999). Description of Cellulophaga baltica gen. nov., sp. nov. and Cellulophaga fucicola gen. nov., sp. nov. and reclassification of [Cytophaga] lytica to Cellulophaga lytica gen. nov., comb. nov. Int J Syst Bacteriol 49, 1231-1240.

Kim, S. B., Falconer, C., Williams, E. \& Goodfellow, M. (1998). Streptomyces thermocarboxydovorans $\mathrm{sp}$. nov. and Streptomyces thermocarboxydus sp. nov., two moderately thermophilic carboxydotrophic species from soil. Int J Syst Bacteriol 48, 59-68.

Kimura, M. (1980). A simple method for estimating evolutionary rates of base substitutions through comparative studies of nucleotide sequences. J Mol Evol 16, 111-120.

Macián, M. C., Pujalte, M. J., Márquez, M. C., Ludwig, W., Ventosa, A., Garay, E. \& Schleifer, K. H. (2002). Gelidibacter mesophilus sp. nov., a novel marine bacterium in the family Flavobacteriaceae. Int J Syst Evol Microbiol 52, 1325-1329.

Marmur, J. (1961). A procedure for the isolation of deoxyribonucleic acid from microorganisms. J Mol Biol 3, 208-218.

Marmur, J. \& Doty, P. (1962). Determination of the base composition of deoxyribonucleic acid from its thermal denaturation temperature. J Mol Biol 5, 109-118.

Nedashkovskaya, O. I., Suzuki, M., Vysotskii, M. V. \& Mikhailov, V. V. (2003a). Reichenbachia agariperforans gen. nov., sp. nov., a novel marine bacterium in the phylum Cytophaga-FlavobacteriumBacteroides. Int J Syst Evol Microbiol 53, 81-85.

Nedashkovskaya, O. I., Kim, S. B., Han, S. K. \& 7 other authors (2003b). Mesonia algae gen. nov., sp. nov., a novel marine bacterium of the family Flavobacteriaceae isolated from the green alga Acrosiphonia sonderi (Kutz) Kornm. Int J Syst Bacteriol 53, 1967-1971.

Nedashkovskaya, O. I., Kim, S. B., Han, S. K., Rhee, M. S., Lysenko, A. M., Falsen, E., Frolova, G. M., Mikhailov, V. V. \& Bae, K. S. (2004a). Ulvibacter litoralis gen. nov., sp. nov., a novel marine bacterium of the family Flavobacteriaceae isolated from the green alga Ulva fenestrata. Int J Syst Bacteriol 54, 119-123.

Nedashkovskaya, O. I., Kim, S. B., Han, S. K. \& 7 other authors (2004b). Maribacter gen. nov., a new member of the family 
Flavobacteriaceae, isolated from marine habitats, containing the species Maribacter sedimenticola sp. nov., Maribacter aquivivus sp. nov., Maribacter orientalis sp. nov. and Maribacter ulvicola sp. nov. Int J Syst Bacteriol 54, 1017-1023.

Saitou, N. \& Nei, M. (1987). The neighbor-joining method: a new method for reconstructing phylogenetic trees. Mol Biol Evol 4, 406-425.
Suzuki, M., Nakagawa, Y., Harayama, S. \& Yamamoto, S. (2001). Phylogenetic analysis and taxonomic study of marine Cytophaga-like bacteria: proposal for Tenacibaculum gen. nov. with Tenacibaculum maritimum comb. nov., and Tenacibaculum ovolyticum comb. nov., and description of Tenacibaculum mesophilum sp. nov. and Tenacibaculum amylolyticum sp. nov. Int J Syst Evol Microbiol 51, 1639-1652. 